\title{
GROEIEN EN OVERLEVEN
}

\author{
door Drs. W. van 't Land en Dr. H. Strasser
}

\section{Probleemstelling}

Jaren van gestadige economische groei hebben in vele ondernemingen het ge. loof doen ontstaan dat groei alleen de doelstelling van de onderneming zou moe. ten zijn. Dit heeft geleid tot een (te) hoog groeitempo. Daarbij zijn grote (vooral financiële) risico's aanvaard. Toen de groei stagneerde moest worden geconstateerd dat de continuiteit van vele ondernemingen in gevaar was gebracht. In die groeijaren werd sterk de rol van het leverage-effekt benadrukt. Immers de ren. testand was ten opzichte van de gemiddelde rentabiliteit (nog) gering. Op zichzelf was het gebruikmaken van het leverage-effekt voor de rentabiliteit op korte ter. mijn wel juist. Het leidde echter tot een vermeerdering van het aandeel van het vreemd vermogen in het totale vermogen. Daarmede werd het financieringsrisico op langere termijn vergroot. Voor de bepaling van de grenzen te stellen aan de toename van het vreemd vermogen ontbrak een theoretische basis.

Groei is een belangrijke doelstelling voor iedere onderneming. Op lange ter. mijn kan de continuilteit van de onderneming alleen dan gewaarborgd blijven, wanneer aard en omvang van haar aktiviteiten afgestemd blijven op zich wijzi. gende externe omstandigheden. Dit heeft betrekking op de produkten die worden vervaardigd, de markten waarop deze produkten worden afgezet, de aard van de produktieprocessen, het kennisniveau van het personeel, etc. De beleidsbeslissingen die de ondernemingsleiding moet nemen, dienen op veranderingen in de externe omgeving van de onderneming te anticiperen. Er is dan nog onzekerheid ten aanzien van de richting, maar vooral ook ten aanzien van het tem. po waarin deze veranderingen zich zullen voltrekken. Nieuwe capaciteiten worden meestal geleidelijk benut. De financiering van nieuwe capaciteiten leidt tot extra aflossings- en renteverplichtingen. De ondernemingsleiding dient er zorg voor te dragen dat de na te streven groei op lange termijn niet tot zodanige fricties op korte en middellange termijn voeren, dat daarmede de continuïteit van de onderneming in gevaar wordt gebracht. Dit afwegingsproces van continuiteit op lange en korte termijn komt in de onderscheiden beleidsaspecten van de on. derneming tot uitdrukking.

In dit artikel zal het financiële afwegingsproces worden behandeld van „groeien”, ter zekerstelling van de continuïteit op lange termijn, en ,overleven”, ter zekerstelling van continuiteit op kortere termijn. Wij zullen de hoofdlijnen aangeven van een model $^{1}$ ), dat voor bedoelde afweging door ons voor ESTEL NV is ontwikkeld.

\footnotetext{
1) Over verwachtingen, teleurstellingen en mogelijkheden van toepassing van modeltechnieken op bestuursniveau zie Heiner Müller Merbach: „Quantitative Entscheidungsvorbereitung” in: Die Betriebswirtschaft, 37 e jaargang 1977, nr. 1 pag. 11.23. Zie ook „An wendungsprobleme moderner Planungs und Entscheidungstechniken" uitgegeven door Hans.Christian Pfohl en Bert Rürup, Königsstein 1978 en „A ktuelle Probleme beider Unterstützung der Unternehmensplanung durch EDV Modelle" van Helge Strasser, Klaus-Dieter Walter en Rolf Wartmann, in Hoesch Berichte aus Forschung und Entwicklung unserer Werke, 1973, nr. 3, pag. 81.87
} 


\section{Groei, risico en rentabiliteit}

In financieel-economische zin komt de kwantitatieve groei $\left.{ }^{2}\right)$ tot uitdrukking in het vastleggen van nieuw vermogen in vast en vlottend kapitaal (investeren). Investeren is noodzakelijk omdat industriële produkten en produktieprocessen een levenscyclus hebben. Produkten of produktieprocessen sterven vroeg of laat uit. Dit komt tot uitdrukking in een teruglopende rentabiliteit. Produkten en processen waarvan de rentabiliteit terugloopt dienen geleidelijk te worden vervangen door nieuwe produkten en processen ter zekerstelling van de continuïteit van de onderneming.

De ondernemingsleiding zal deze cyclus van groeien en vergaan in balans moe. ten houden. De omstructurering naar nieuwe produkten en processen zal veelal haar financiële basis in de bestaande aktiviteiten moeten vinden. Het investe. ringsbeleid dient derhalve zowel gericht te zijn op het gezondhouden van de be staande aktiviteiten als op het omstructureren naar andere aktiviteiten.

In een strategisch plan zal dit beleid nader uitgewerkt dienen te zijn naar aard en omvang van bestaande en nieuwe aktiviteiten op basis van prognoses van de externe omgeving. In het operationele plan worden in het kader van dit beleid concrete projekten opgenomen. In deze plannen zullen rentabiliteitsverwachtin. gen worden uitgewerkt en tevens aangegeven worden welke bijdragen nieuwe projekten daaraan leveren.

Nieuwe investeringen zijn dus noodzakelijk om de rentabiliteit van de onder. neming op lange termijn tenminste in stand te houden of zo mogelijk te verbe. teren. Omgekeerd bepaalt echter het niveau van de rentabiliteit op lange termijn het niveau van het te volgen groei- of investeringstempo. De mate waarin de omvang van het eigen vermogen kan worden verhoogd door winstinhouding en/of kapitaalemissie is immers afhankelijk van de rentabiliteitsverwachting. Het aldus vergrote eigen vermogen is weer bepalend voor de mogelijkheid om rentedra. gend vreemd vermogen aan te trekken.

Hiermede komen wij op wat wij in dit artikel ,het overlevingsaspekt" noemen. Wat „risicomijdend" vermogen (= leningen) voor de kapitaalverstrekker is, is „risicobrengend" voor de onderneming. Immers, de toekomstige resultaten moeten van zodanige omvang zijn dat de uit deze vermogensvorm voortvloeiende con. tractuele verplichtingen (rente en aflossingen) kunnen worden nagekomen.

Tussen de drie grootheden groei, risico en rentabiliteit bestaat een interdepen. dent verband ${ }^{3}$ ) dat als volgt kan worden weergegeven:

\footnotetext{
2) Een goed overzicht over maatstaven voor ondernemingsgroei geeft Hans Münstermann in „Zum Problem der Planung und Kontrolle des betrieblichen Wachstums" in Zeitschrift fur Betriebswirtschaft, $1968 \mathrm{nr}$. 10, blz. 727.747.

Zie ook Thomas Ludwig "Optimaie Expansionspfade der Unternehmung”, Wiesbaden 1978, pag. 19 e.v. en de in dit kader aangegeven literatuur.

3) L Traas noemt de variabelen rencabiliteitseis, groeitempo en risicopreferenties in ,Inflatie en financiering", in Bedrijfskun de, jaargang 46,1974/1 pag. 6.27.

Arno Eisenhofer baseert zijn kencijfermodel op drie hoofddoeleinden ..Gesamtrentabilität, Wachstumsrate und Personallei stung" in ,Zielvereinbarung in der Unternehmensplanung", in Zeitschrift für Betriebswirıschaft, 42e jaargang 1972 pag. 618.628.

Helge Strasser noemt in "Zielbildung und Steuerung der Unternehmung”, Wiesbaden 1966 op pag. 46 „Gesamtkapitalrendite, Marktanteil und Liquiditäı" als hoofddoelen.
} 
Rentabiliteit

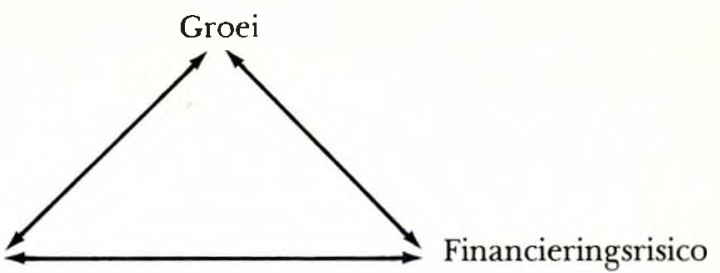

In een comparatief statische vorm kan deze relatie ook als volgt worden uitgewerkt. Wij gaan daarbij uit van een onderneming, waarvan het totale kapitaal $\left(\mathrm{V}^{4}\right)$ gefinancierd wordt met eigen vermogen (EV) in de vorm van aandelenkapitaal ${ }^{5}$ ) en reserves en vreemd vermogen (VV) in de vorm van schulden en voorzieningen.

$$
\text { (1) } \mathrm{V}=\mathrm{EV}+\mathrm{VV} \text {. }
$$

Van de in deze formule impliciet weergegeven risicobereidheid (RB) van de ondernemingsleiding kan een momentopname worden gemaakt in de formule:

$$
\text { (2) } \mathrm{RB}=\frac{\mathrm{VV}}{\mathrm{EV}} \text {. }
$$

Uit de formules (1) en (2) kan worden afgeleid:

(3) $\mathrm{V}=\mathrm{EV}(\mathrm{RB}+1)$

Groei van het totale vermogen van de onderneming kan als volgt worden uitgedrukt:

$$
\text { (4) } \triangle \mathrm{V}=\triangle \mathrm{EV}(\mathrm{RB}+1) \text {. }
$$

Groei van het eigen vermogen ontstaat bij interne financiering uit netto winst (W) verminderd met dividenduitkering (D):

$$
\text { (5) } \quad \triangle \mathrm{EV}=\mathrm{W}-\mathrm{D} \text {. }
$$

Voorgaande formules kunnen ook uitgedrukt worden in de groeivoet van het totale vermogen van de onderneming:

(6) $\frac{\Delta V}{V}=\left(\frac{W}{V}-\frac{D}{V}\right)(R B+1)$ en

(7) $g_{v}=\left(r_{v}-d_{v}\right)(R B+1)$.

Waarbij $g_{v}$ de groeivoet van het totale in de onderneming gestoken vermogen is, $r_{v}$ de rentabiliteit van dat vermogen na belasting en $d_{v}$ de dividendpolitiek in relatie tot het totale vermogen.

\footnotetext{
4) Uitgegaan wordt van de korte balans waarbij handelsvorderingen en schulden gesaldeerd zijn. Bedrijfskapitaal is de som van dit saldo met de voorraden.

5) Uitgegaan wordt van de balanswaarde.
} 
Ervan uitgaande dat er een vaste relatie bestaat tussen $d_{v}$ en $r_{v}$ blijkt dat een zelfde groeitempo van de onderneming bereikt kan worden bij hoge rentabiliteit en geringe risicobereidheid en omgekeerd. In isogroeicurven kan worden weer. gegeven, door welke combinatie van risicobereidheid (RB) en rentabiliteit $\left(r_{v}\right)$ een zelfde groeivoet $\left(\mathrm{g}_{\mathrm{v}}\right)$ realiseerbaar is. In de grafieken 1 en 2 zijn bedoelde isogroei. curven weergegeven waarbij $\mathrm{g}_{\mathrm{v} 1}<\mathrm{g}_{\mathrm{v} 2}<\mathrm{g}_{\mathrm{v} 3}<\mathrm{g}_{\mathrm{v} 4} \ldots$
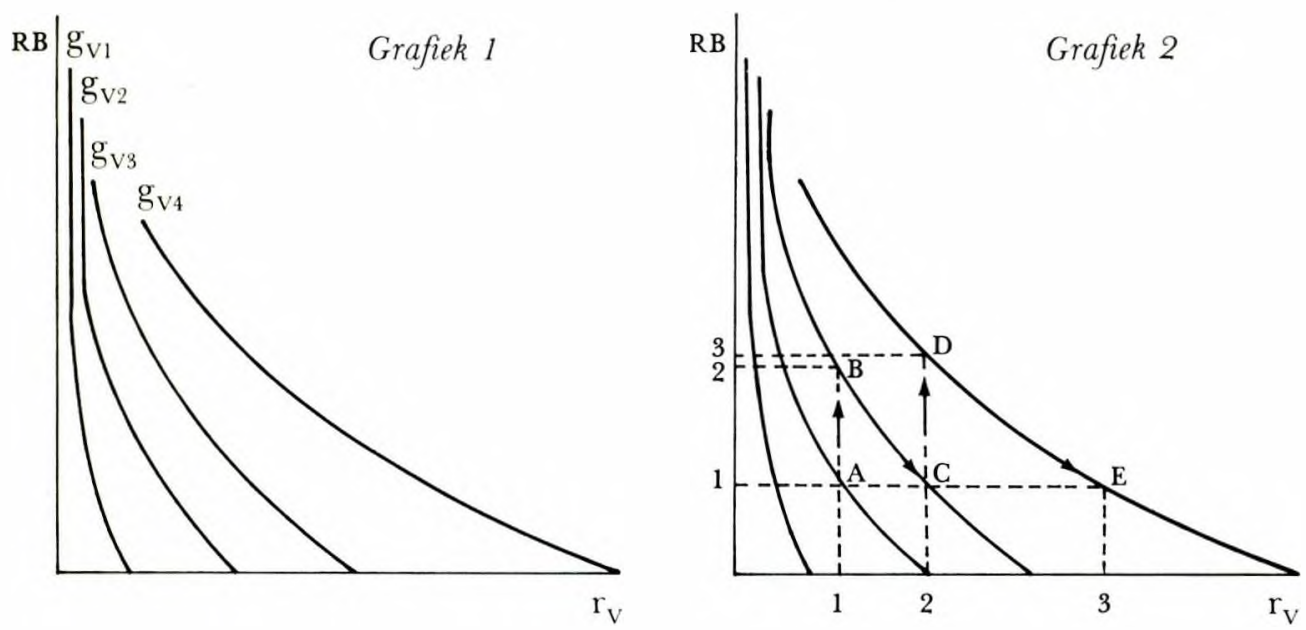

In grafiek 2 wordt de weg aangegeven die de onderneming kan volgen wanneer deze zijn groeitempo wil verhogen van $g_{\mathrm{v} 2}$ naar $g_{\mathrm{v} 4}$ bij onveranderde risicobereid. heid (RB) op lange termijn.

Dit doel is alleen bereikbaar wanneer door dit beleid de rentabiliteit van de on. derneming kan worden verhoogd van $r_{v 1}$ naar $r_{v 3}$. Ervan uitgaande dat in de uit. gangssituatie A met minimale kosten wordt geproduceerd kan het ten doel gestelde punt $E$ slechts bereikt worden door nieuwe inv'steringen met een zodanige rentabiliteit dat daardoor de ten doel gestelde rentabiliteitsverbetering ook kan worden bereikt.

Voor de financiering van de nagestreefde groei zal in vele gevallen een beroep moeten worden gedaan op vreemd vermogen. De ten doel gestelde rentabiliteits. verbetering kan daardoor mede worden ondersteund door een verhoogde leveragefaktor. Vergroting van het aandeel van het vreemd vermogen in het totale ver. mogen betekent echter tevens een vergroting van het financieringsrisico. In ons voorbeeld is ervan uitgegaan, dat de ten doel gestelde verhoging van het groeitem. po en de daarmede verbonden (noodzakelijke) verhoging van de rentabiliteit in twee stappen wordt bereikt. Het groeitempo wordt eerst verhoogd van $g_{v 2}$ naar $g_{v s}$. Deze stijging van het groeitempo wordt geheel gefinancierd door het aantrekken van vreemd vermogen. De risicobereidheid stijgt daardoor naar $\mathrm{RB}_{2}$ (punt $B$ ). Ver. volgens worden de extra winsten gebruikt om het vreemd vermogen weer zover te verminderen dat de oorspronkelijke vermogensverhouding behorende bij $R_{1}$ weer wordt hersteld (punt C), van daaruit wordt een nieuwe groei-impuls gegeven (punt D), gevolgd door een herstel van de oorspronkelijke vermogensverhouding (punt E).

Als hulpmiddel voor de vaststelling van een aanvaardbaar groeitempo wordt bij 
ESTEL een financiële ruimte-berekening gemaakt, die op deze gedachte is geënt.

\section{Financiële ruimte}

Is (het verloop van) de rentabiliteitsverwachting of doelstelling gegeven en (het ver. loop van) het financiële risico, dat in de komende periode aanvaardbaar wordt ge. acht, vastgesteld dan kan daaruit afgeleid worden welk bedrag maximaal beschik baar komt voor investeringen. Na aftrek van betalingen voor instandhoudings-, sociale en milieu investeringen, alsmede betalingen op reeds goedgekeurde investeringen, blijft een bedrag over dat vrij ter beschikking is voor nieuwe strategische in. vesteringen en om weerstand te kunnen bieden tegen eventueel ongunstige exter. ne ontwikkelingen.

Dit bedrag wordt „financiële ruimte"6) genoemd. Hoe groter deze financiële ruimte is, des te groter is de strategische beslissingsvrijheid van de onderneming. De berekening van de financiële ruimte is in principe eenvoudig. $\mathrm{Zij}$ is gebaseerd op ramingen of doelstellingen t.a.v.:

- Resultaat voor afschrijvingen en rente?)

- Afschrijvingen

- Rente

$=$ Resultaat voor belasting

- Belastingen

$=$ Netto winst

- Dividend

$=$ Mutatie van het eigen vermogen

+ Mutatie van het niet rentedragend vreemd vermogen

+ Mutatie van het rentedragend vreemd vermogen

+ Afschrijvingen

+ Desinvesteringen

= Maximaal beschikbaar vermogen voor investeringen

- Betalingen op goedgekeurde alsmede nieuw geplande produktiewaarborgende investeringen ${ }^{8}$ )

- Betalingen op reeds goedgekeurde strategische investeringen

- Mutatie van het bedrijfskapitaal als gevolg van groei binnen potentiële capaciteiten op grond van besloten en geplande investeringen

$=$ Financiële ruimte voor nieuwe strategische investeringen in duurzame produktiemiddelen en deelnemingen alsmede daarmede verbonden verhoging van het bedrijfskapitaal.

In dit overzicht is buiten beschouwing gelaten de financiële ruimte die ontstaat als gevolg van de verhoging van het risicodragend vermogen door aandelenemis. sies.

\footnotetext{
6) Thomas Ludwig gaat in „Optimale Expansionspfade der Untemehmung” uit van de begrippen „Investitionsspielraum” en „Verschuldungsspielraum

F. W. C. Blom gaat uit van het begrip „speelnimte aan ongebruikte leencapaciteit”, in „Leencapaciteit van Ondernemingen” in Be driffsunde, jaargang 46, 1974/4, pag. 213.220.

) In dit rekenschema wordt uitgegaan van resuitaten vóór afschrijvingen en rente omdat hiermede het beste het winstpotentieel van de onderneming tot uitdrukking wordt gebracht. De wijze van financiering(rente) en kapitaalstruktuur (afschrijvingen)blijven im mers buiten beschouwing. Daarom ook verdient bij vergelijking naar winstg evendheid van verschillende ondernemingen of van de onderscheiden activiteitengebieden van dezelfde ondememing dit resultatenbegrip de voorkeur.

${ }^{\circ}$ ) Zie definitie hiervan op pag. 10.
} 
De drie eerder genoemde basisvariabelen zijn in dit rekenschema te herkennen:

Rentabiliteit: resultaat in relatie tot het vermogen

$$
\begin{aligned}
& r_{\mathrm{VBR}}=\text { resultaat voor belastingen, afschrijvingen en rente } \\
& r_{\mathrm{V} V \mathrm{r}}=\text { resultaat voor belastingen en rente } \\
& r_{\mathrm{V}}=\text { resultaat na belastingen }
\end{aligned}
$$

Risico: verhouding tussen eigen vermogen enerzijds en niet rentedragend en rentedragend vreemd vermogen anderzijds.

Groei:

maximaal beschikbaar vermogen voor investeringen op basis van winstinhouding en mutatie van het vreemd vermogen.

De omvang van de financiële ruimte vloeit voort uit de onderlinge afstemming van deze drie basisvariabelen. Uit par. 2 blijkt tevens dat vele combinaties van risicobereidheid en rentabiliteit een zelfde financiële ruimte voor strategische investeringen opleveren. Deze combinaties liggen op dezelfde isogroeicurve.

In het navolgende wordt de relatie uitgewerkt tussen de rentabiliteit van de onderneming en de risicobereidheid waaruit een norm voor het financieringsrisico kan worden afgeleid.

\section{Norm ter vaststelling van het financieringsrisico}

In de timelag die er bestaat tussen het vastleggen van het vermogen en het weer vrijkomen daarvan loopt de onderneming risico over dit vermogen. Deze risico's moeten aanvaard worden om winst- en groeidoeleinden te kunnen realiseren. Anderzijds echter moeten deze groei-en winstdoeleinden afgewogen worden met de omvang van het financieringsrisico, opdat de continuilteit van de reeds bestaande aktiviteitengebieden daardoor niet in gevaar wordt gebracht. Derhalve is het noodzakelijk over een maatstaf voor de vaststelling van de grootte van dit financieringsrisico te beschikken. ${ }^{9}$ )

Een veel toegepaste en tevens een zeer eenvoudige maatstaf is het aandeel van het eigen vermogen in het totale vermogen. Een dergelijke maatstaf kan slechts indicatief van aard zijn daar de eigenlijke risicofaktoren daarin niet - tenminste niet expliciet - tot uitdrukking worden gebracht. Hoogstens kan worden vastgesteld dat een daling van het aandeel van het eigen vermogen in het totale vermogen een vergroting van het financieringsrisico betekent. Niet kan worden vastgesteld welk aandeel van het eigen vermogen in het totale vermogen uit risicooogpunt aanvaardbaar is. $\left.{ }^{10}\right)$

In de literatuur worden ook andere maatstaven voor het financieringsrisico genoemd die o.a. gebaseerd zijn op de volgende kengetallen: ${ }^{11}$ )

- liquide middelen in verhouding tot het investeringsbedrag

- liquide middelen in verhouding tot de jaaromzet

\footnotetext{
9) Thomas Ludwig vermeldt op pag. 57 e.v. in „Optimale Expansionspfade der Unternehmung”, welke maatstaven er gehan. teerd worden voor de vaststelling van een aanvaardbare omvang van het financieringsrisico.

10 Zie ook F. W. C. Blom, „Leencapaciteit van ondernemingen" op pag. 216.

11) Zie Helmut Koch: „Zum Verfahren der strategischen Programmplanung”, in ZfbF, 3le jaargang 1979, pag. 145-161.
} 
- verhouding lange en korte schulden

- cash flow in verhouding tot de netto aflossingsverplichtingen.

Ook deze kengetallen hebben slechts een indicatief karakter.

Door ons wordt een criterium gehanteerd waarin de (financierings-) risicofak. toren expliciet tot uitdrukking worden gebracht, op basis waarvan een uitspraak kan worden gedaan over het niveau van een aanvaardbaar financieringsrisico in relatie tot de variabelen groei en rentabiliteit. Dit criterium wordt „normaal financieringsrisico" genoemd.

\section{Normaal financieringsrisico}

Het criterium „normaal financieringsrisico" is gebaseerd op een mutatiebalans ${ }^{12}$ ) van het vermogen:

Mutatiebalans van het vermogen

\begin{tabular}{|c|c|}
\hline $\begin{array}{l}\text { Resultaat voor afschrijvingen en } \\
\text { rente }\end{array}$ & $\begin{array}{l}\text { - Aflossingen } \\
\text { - Rente } \\
\text { - Dividend } \\
\text { - Belastingen } \\
\text { - Produktiewaarborgende } \\
\quad \text { investeringen }\end{array}$ \\
\hline $\begin{array}{l}\text { - Mutatie van het niet rentedragend } \\
\text { vreemd vermogen } \\
\text { - Mutatie van het rentedragend } \\
\text { vreemd vermogen } \\
\text { - revolvering } \\
\text { - netto kredietopname } \\
\text { - Desinvesteringen }\end{array}$ & $\begin{array}{l}\text { - Strategische investeringen } \\
\text { - grote vervangingen } \\
\text { - capaciteitsgroei } \\
\text { - deelnemingen } \\
\text { - bedrijfskapitaal }\end{array}$ \\
\hline Herkomst van middelen & Besteding van middelen \\
\hline
\end{tabular}

Het financieringsrisico wordt „normaal” geacht indien op lange termijn (bv. gemiddeld per jaar over een periode van 2 conjunctuurcycli) uit de lopende inkomsten in de vorm van resultaat voor belastingen, afschrijvingen en rente, de betalingsverplichtingen uit hoofde van aflossingen, rente, dividenden, belastingen en produktiewaarborgende investeringen kunnen worden gefinancierd. ${ }^{13}$ )

Hierbij zijn twee vooronderstellingen van belang:

- De aflossingen van het rentedragend vreemd vermogen moeten uit de lopende inkomsten betaald kunnen worden opdat de revolvering daarvan gebruikt kan worden voor de financiering van strategische investeringen.

\footnotetext{
1-) Deze gedachte is op zichzelf niet nieuw. Zie daartoe o.a. Walther Busse von Colbe „Aufbau und lnformationsgehalt von Kapiralflussrechnungen" in Zeitschrift für Betriebswirtschaft, 36e jaargang 1966, pag. 82114.

, Een overeenkomstige doch veel conservatievere maatstaf is door Gordon Donaldson uitgewerkt in "Corporate Debt Po licy", Boston 1961. Een samenvatting hiervan is te vinden in Harvard Business Review 1962, pag. 117-131, "New Framework for Corporate Debt Policy”. Zie tevens Hans E. Büschgen: "Zunehmende Fremdfinanzierung und Insolvenzgefahr” in Betriebs. wirtschaftliche Forschung und Praxis, 27e jaargang 1975, pag. 107.
} 
- Evenzo moeten produktiewaarborgende investeringen uit de lopende inkomsten worden gefinancierd.

Produktiewaarborgende investeringen zijn investeringen die nodig zijn om de economische levensduur van alle in bedrijf zijnde hoofdinstallaties zeker te stellen, alsmede sociale en milieu-investeringen. Ook worden daartoe gerekend eventue. le (strukturele) verhogingen van het bedrijfskapitaal, die voor de doorvoering van de bestaande aktiviteiten noodzakelijk zijn. Vervanging van in bedrijf zijnde hoofdinstallaties wordt tot de strategische investeringen gerekend, daar de beslissing over vervanging van deze installaties versus omstructurering naar nieuwe ak. tiviteiten, een strategische beslissing is.

Met andere woorden het financieringsrisico is normaal, wanneer slechts de strategische investeringen inclusief de grotere vervangingsinvesteringen, alsme. de daarmede verbonden (strukturele) verhogingen van het bedrijfskapitaal met vreemd vermogen eventueel door desinvesteringen kunnen worden gefinancierd.

Uit de mutatiebalans kunnen tevens de omvang en aard van de financieringsrisico's worden afgeleid:

- De continuïteit op lange termiin komt in gevaar omdat:

- er geen financiële ruimte meer is voor nieuwe strategische investeringen de reeds besloten en in uitvoering zijnde strategische investeringen stilge. legd moeten worden.

- De continuïteit op korte termijn komt in gevaar omdat:

- de onderneming geen middelen heeft om de kapitaalgoederen in stand te houden en/of te voldoen aan wettelijke verplichtingen

de onderneming niet meer kan voldoen aan de aan het beschikbaar gestel. de vermogen verbonden verplichtingen (rente en aflossingen).

De norm „normaal financieringsrisico”, kan vertaald worden in balansverhoudingen zoals b.v. het aandeel van het eigen vermogen in het totale vermogen.

Deze vertaling leidt echter niet tot vaste maar tot variabele verhoudingsgetal. len al naar gelang de verwachtingen die de ondernemingsleiding heeft c.q. de doelstellingen die deze kiest voor de bij de dynamische balansbeschouwing gehanteerde grootheden. In tabel 1 zijn deze relaties voor een gefingeerde onderneming uitgewerkt. Hierbij wordt het aandeel van het eigen vermogen in het totale vermogen gegeven in relatie tot de belangrijkste bij de in dit artikel, voor het be. doelde afwegingsproces, gehanteerde grootheden. Hierbij dient te worden aan. getekend dat een dergelijk dynamisch model slechts door uitschakeling van de tijdsfaktor in een comparatief statische vorm kan worden weergegeven. Of an. ders gesteld: de bij dit afwegingsproces gehanteerde uitgangspunten worden in de tijd gezien als constanten verondersteld. Zouden deze uitgangspunten gemid. deld in de tijd gezien een niveau hebben zoals omrand is aangegeven, dan kan daaruit afgeleid worden dat de betreffende onderneming een gemiddeld aandeel van het eigen vermogen in het totale vermogen van $35 \%$ zal moeten nastreven ${ }^{14}$ :

\footnotetext{
14) Hierbij is uitgegaan van de volgende relatie:

$s-1-\frac{R_{V B R}[1-s-c(1-s)]+s \cdot a+c \cdot a(1-s)-p}{\frac{h}{t}+f \cdot h[1-s-c(1-s)]}$
}

Zie voor de verklaring van de symbolen de tabel op pag. 11 


\begin{tabular}{|c|c|c|c|c|c|c|}
\hline \multicolumn{7}{|c|}{ Aandeel in eigen vermogen in $\%(x)$ bij normale financieringsrisico } \\
\hline \multirow{2}{*}{\multicolumn{2}{|c|}{ Risicofaktoren }} & \multicolumn{5}{|c|}{$\begin{array}{l}\text { Bijeen rentabiliteit voor } \\
\text { afschrijuingen en rente }\left(r_{\forall B R}\right) \text { in } \\
\% \text { van: }\end{array}$} \\
\hline & & 9 & 10 & 11 & 12 & 13 \\
\hline $\begin{array}{l}\text { Aflossingstermijn van het rentedragend } \\
\text { vreemd vermogen in jaren }(\mathrm{t})\end{array}$ & $\begin{array}{r}10,5 \\
9,5 \\
8,5 \\
7,5 \\
6,5\end{array}$ & $\begin{array}{l}30 \\
35 \\
41 \\
47 \\
54\end{array}$ & $\begin{array}{l}25 \\
32 \\
38 \\
45 \\
51\end{array}$ & $\begin{array}{l}22 \\
29 \\
35 \\
42 \\
49\end{array}$ & $\begin{array}{l}18 \\
25 \\
32 \\
39 \\
46\end{array}$ & $\begin{array}{l}15 \\
22 \\
29 \\
36 \\
14\end{array}$ \\
\hline $\begin{array}{l}\text { Rentevoet van het rentedragend vreemd } \\
\text { vermogen in } \%(\mathrm{f})\end{array}$ & $\begin{array}{c}7 \\
8 \\
9 \\
10 \\
11\end{array}$ & $\begin{array}{l}40 \\
40 \\
41 \\
42 \\
43\end{array}$ & $\begin{array}{l}36 \\
37 \\
38 \\
39 \\
40\end{array}$ & \begin{tabular}{|l|}
33 \\
34 \\
35 \\
36 \\
37
\end{tabular} & $\begin{array}{l}30 \\
31 \\
32 \\
33 \\
34\end{array}$ & $\begin{array}{l}27 \\
28 \\
29 \\
30 \\
31\end{array}$ \\
\hline Dividend in $\%$ van de netto winst (c) & $\begin{array}{l}50 \\
55 \\
60 \\
65 \\
70\end{array}$ & $\begin{array}{l}41 \\
41 \\
41 \\
42 \\
42\end{array}$ & $\begin{array}{l}37 \\
38 \\
38 \\
39 \\
40\end{array}$ & $\begin{array}{l}33 \\
34 \\
35 \\
36 \\
37\end{array}$ & $\begin{array}{l}29 \\
31 \\
32 \\
33 \\
35\end{array}$ & $\begin{array}{l}26 \\
27 \\
29 \\
30 \\
32\end{array}$ \\
\hline $\begin{array}{l}\text { Afschrijuingen in } \% \text { van het totale } \\
\text { vermogen (a) }\end{array}$ & $\begin{array}{c}6,5 \\
6,1 \\
5,7 \\
5,3 \\
4,9\end{array}$ & $\begin{array}{l}31 \\
36 \\
41 \\
46 \\
51\end{array}$ & $\begin{array}{l}28 \\
33 \\
38 \\
43 \\
48\end{array}$ & $\begin{array}{l}25 \\
30 \\
35 \\
40 \\
45\end{array}$ & $\begin{array}{l}22 \\
27 \\
32 \\
37 \\
42\end{array}$ & $\begin{array}{l}19 \\
24 \\
29 \\
34 \\
39\end{array}$ \\
\hline $\begin{array}{l}\text { Aandeel prod. waarb. invest. in \% van het } \\
\text { totale vermogen (p) }\end{array}$ & $\begin{array}{l}2,2 \\
2,4 \\
2,6 \\
2,8 \\
3,0\end{array}$ & $\begin{array}{l}35 \\
38 \\
41 \\
44 \\
48\end{array}$ & $\begin{array}{l}32 \\
35 \\
38 \\
41 \\
44\end{array}$ & $\begin{array}{l}29 \\
32 \\
35 \\
38 \\
41\end{array}$ & $\begin{array}{l}26 \\
29 \\
32 \\
35 \\
38\end{array}$ & $\begin{array}{l}22 \\
26 \\
29 \\
32 \\
35\end{array}$ \\
\hline $\begin{array}{l}\text { A andeel rentedragend vreemd vermogen } \\
\text { in } \% \text { van het totale vreemd vermogen }(\mathrm{h})\end{array}$ & $\begin{array}{l}43 \\
45 \\
{[47]} \\
49 \\
51\end{array}$ & $\begin{array}{l}36 \\
39 \\
41 \\
44 \\
46\end{array}$ & $\begin{array}{l}32 \\
35 \\
38 \\
41 \\
43\end{array}$ & $\begin{array}{l}29 \\
32 \\
35 \\
38 \\
40\end{array}$ & $\begin{array}{l}26 \\
29 \\
32 \\
35 \\
37\end{array}$ & $\begin{array}{l}22 \\
26 \\
29 \\
32 \\
34\end{array}$ \\
\hline Belastingen in $\%$ van de netto winst (s) & $\begin{array}{l}46 \\
48 \\
50 \\
52 \\
54\end{array}$ & $\begin{array}{l}41 \\
41 \\
41 \\
41 \\
41\end{array}$ & $\begin{array}{l}38 \\
38 \\
38 \\
38 \\
39\end{array}$ & $\begin{array}{l}34 \\
35 \\
35 \\
35 \\
36\end{array}$ & $\begin{array}{l}31 \\
31 \\
32 \\
32 \\
33\end{array}$ & $\begin{array}{l}28 \\
28 \\
29 \\
29 \\
30\end{array}$ \\
\hline
\end{tabular}


Uit tabel 1 is voorts af te lezen dat het financieringsrisico groter wordt - en daarmede dat tevens het na te streven aandeel van het eigen vermogen in het totale vermogen hoger zal dienen te zijn - wanneer:

- de rentabiliteitsverwachtingen pessimistischer zijn

- de leningsvoorwaarden ongunstiger zijn

- op grond van geringere risicobereidheid van economische subjekten hogere dividendpercentages worden verlangd

- de kapitaalgoederen verouderd zijn c.q. de maatschappij hogere sociale en mi lieu.eisen stelt

- de belastingen hoger worden

- de verhouding handelsvorderingen/handelsschulden ongunstiger wordt bv. ten gevolge van een zwakkere marktpositie.

\section{Groeien: zoeken naar nieuwe evenwichten}

De hiervoor uitgewerkte relatie tussen risicobereidheid en rentabiliteit kan grafisch als volgt worden weergegeven ${ }^{15}$ :

In grafiek 3 geven de curven $\mathrm{NR}_{1}$ en $\mathrm{NR}_{2}$ aan welke risicobereidheid (RB) „,normaal" is in relatie tot de verwachte of ten doel gestelde rentabiliteit $\left(r_{v}\right)$ op basis van alternatieve niveaus ten aanzien van leningsvoorwaarden, dividendpolitiek, aandeel niet rentedragend vreemd vermogen, niveau van afschrijvingen en pro. duktiewaarborgende investeringen (zie tabel 1). Daarbij zijn de kredietvoorwaarden die aan $\mathrm{NR}_{1}$ ten grondslag liggen aanzienlijk gunstiger dan die ten grondslag liggen aan $\mathrm{NR}_{2}$. De snijpunten van de lijnen NR met $g_{\mathrm{V}}$ geven dan de punten aan waar sprake is van een ,evenwichtige" groei, waarbij voldaan is aan in beide relaties vastgelegde voorwaarden.

De relatie tussen de uitgangspunten en/of doelstellingen die ten grondslag lig. gen aan het rentabiliteitsniveau en aan het financieringsrisico kunnen in een simulatiemodel nader worden uitgewerkt. Dit model is de basis voor een dialoog tussen onderscheiden bestuursniveaus binnen de onderneming en met belangengroepen bij de onderneming over ondernemingsplannen en het in dit kader vast te stellen investerings- en financieringsbeleid.

\footnotetext{
15) Hierbij is uitgegaan van de volgende uitgangspunten: aflossingstermijn van het rentedragend veemd vermogen in jaren $t=8,5$ rencevoet van het rentedragend vreemd vermogen $\quad f=0,09$ aandeel van het dividend in de netto winst aandeel van de afschrijvingen in het totale vermogen aandeel prod. waarb. invest in het totale vermogen aandeel rentedragend in het totale vreemd vermogen aandeel belastingen in de netto winst

Voorts is in ، lir worbeeld aangenomen dat deze uitgangspunten in de loop van de periode constant blijven c.q. elkaar onderling niet beïnuloeden.

Uit de hiervoor genoemde formules kan worden afgeleid:

groeifunktie:

$$
g_{V}=0,4 r_{V}(R B+1)
$$

risicohunktie NR,$$
R B=\frac{0.0673}{0,3811-6,274 r_{V}}-1
$$

risicofunkie $N R_{q}$ is opgesteld bij een aflossingstermijn $t=7,5$

$$
R B=\frac{0,8811}{0,4453-5,6235 r_{V}}-1
$$




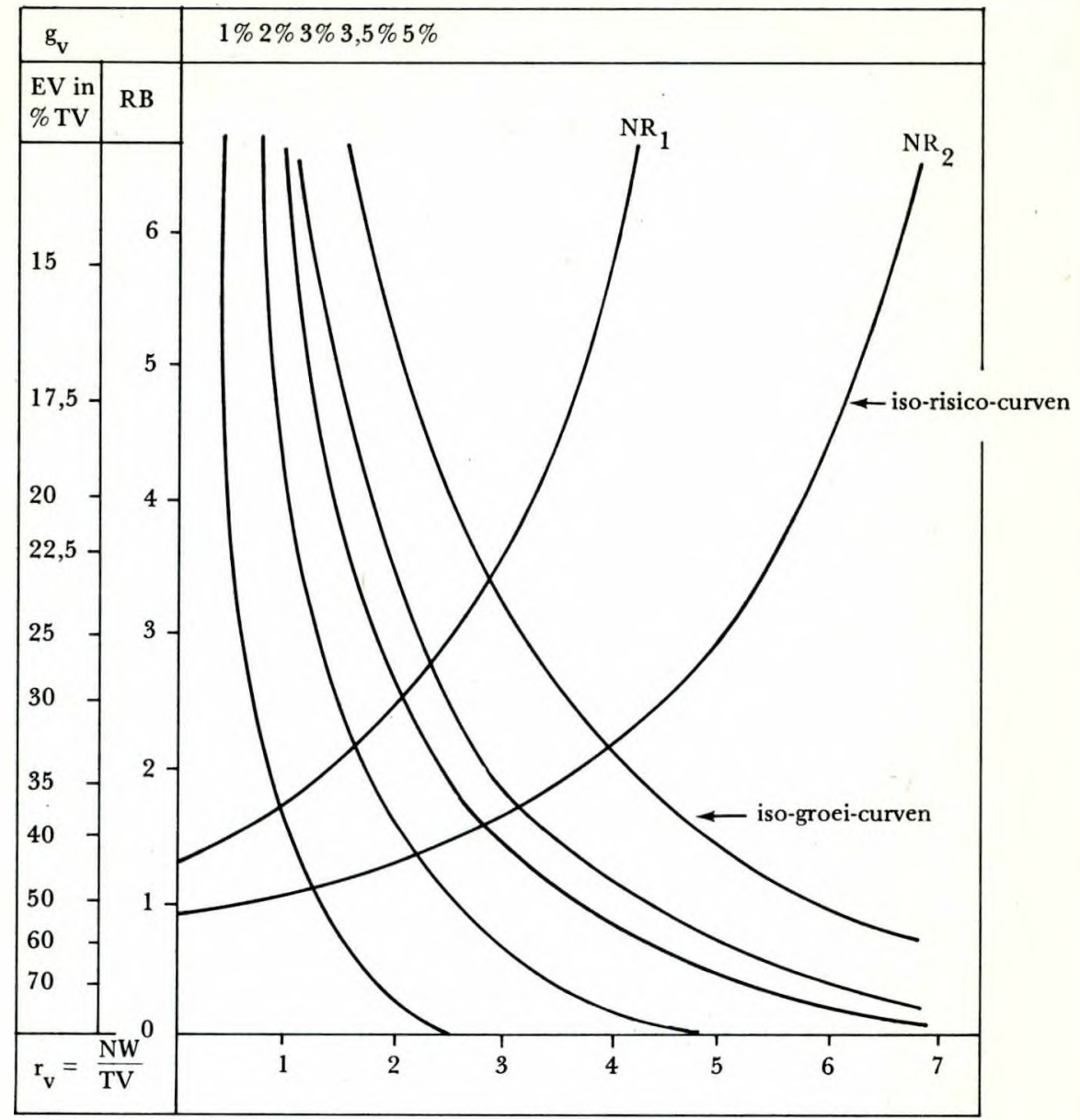

In het navolgende zeer vereenvoudigde voorbeeld wordt het karakter van dit afwegingsproces weergegeven. Daarbij wordt ervan uitgegaan dat de onderneming in de uitgangssituatie A (zie grafiek 4) haar groei op lange termijn van ge. middeld $5 \%$ per jaar gebaseerd had op een rentabiliteitsverwachting $r_{v}$ van de bestaande aktiviteitengebieden van $2,9 \%$ bij normaal risico $\mathrm{NR}_{1}$. Voorts wordt verondersteld dat de nieuw ingediende strategische plannen uitgaan van een ver. slechtering van de rentabiliteitsverwachting van de bestaande aktiviteitengebie den naar een $r_{v}$ van $2,1 \%$ en dat de aflossingstermijn van het rentedragend vreemd vermogen daalt van gemiddeld 8,5 jaar naar 7,5 jaar, zodat curve $\mathrm{NR}_{1}$ verschuift naar $\mathrm{NR}_{2}$.

Zou de ondernemingsleiding slechts haar groeitempo verlagen van $5 \%$ naar $3,5 \%$ (zie grafiek 5), doch haar RB handhaven op 3,3 (=23\% EV in TV) dan volgt de onderneming geen evenwichtig groeibeleid. Dit groeibeleid gaat uit van een financiering met een meer dan „normaal” risico. 


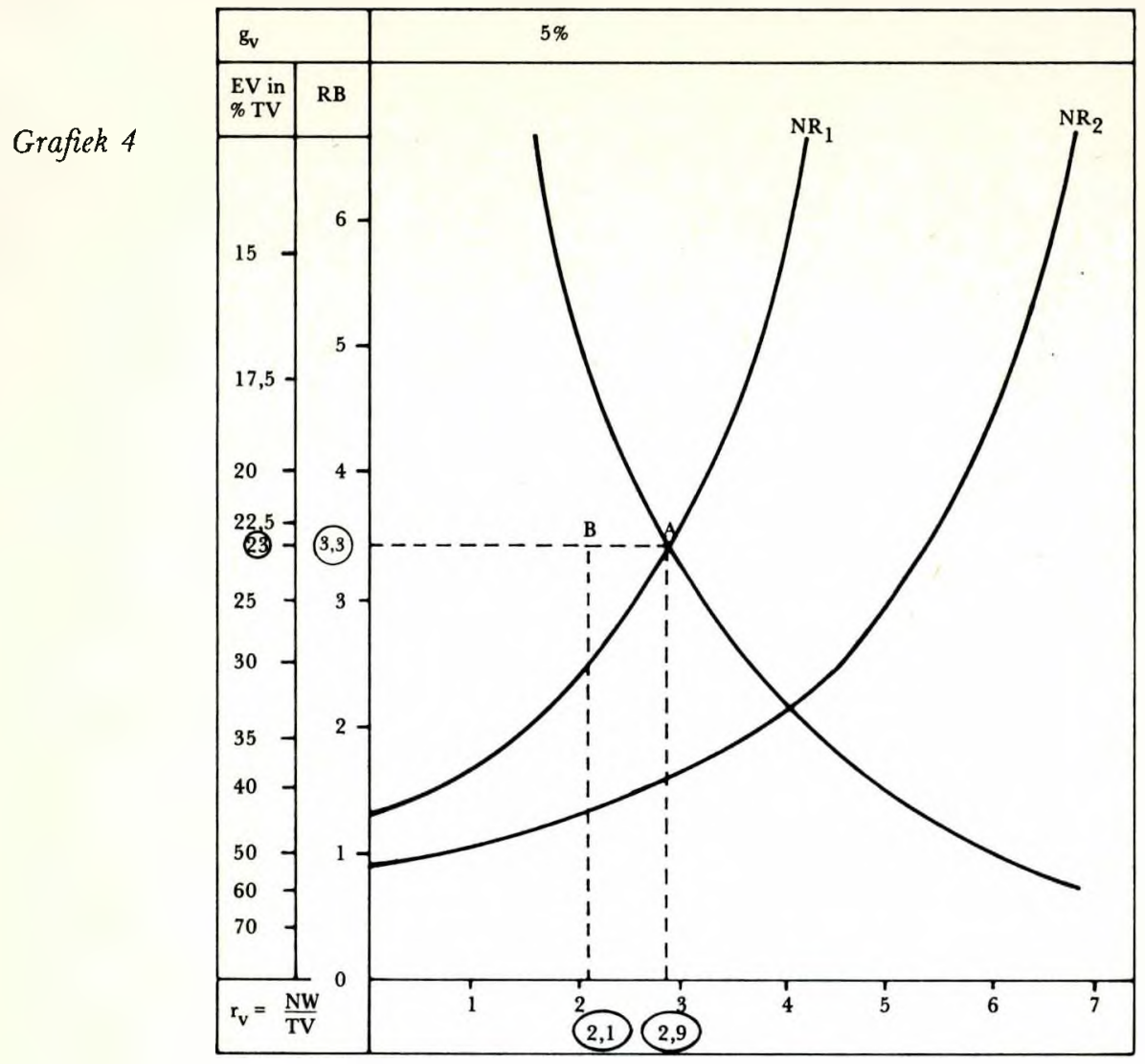

Grafiek 5

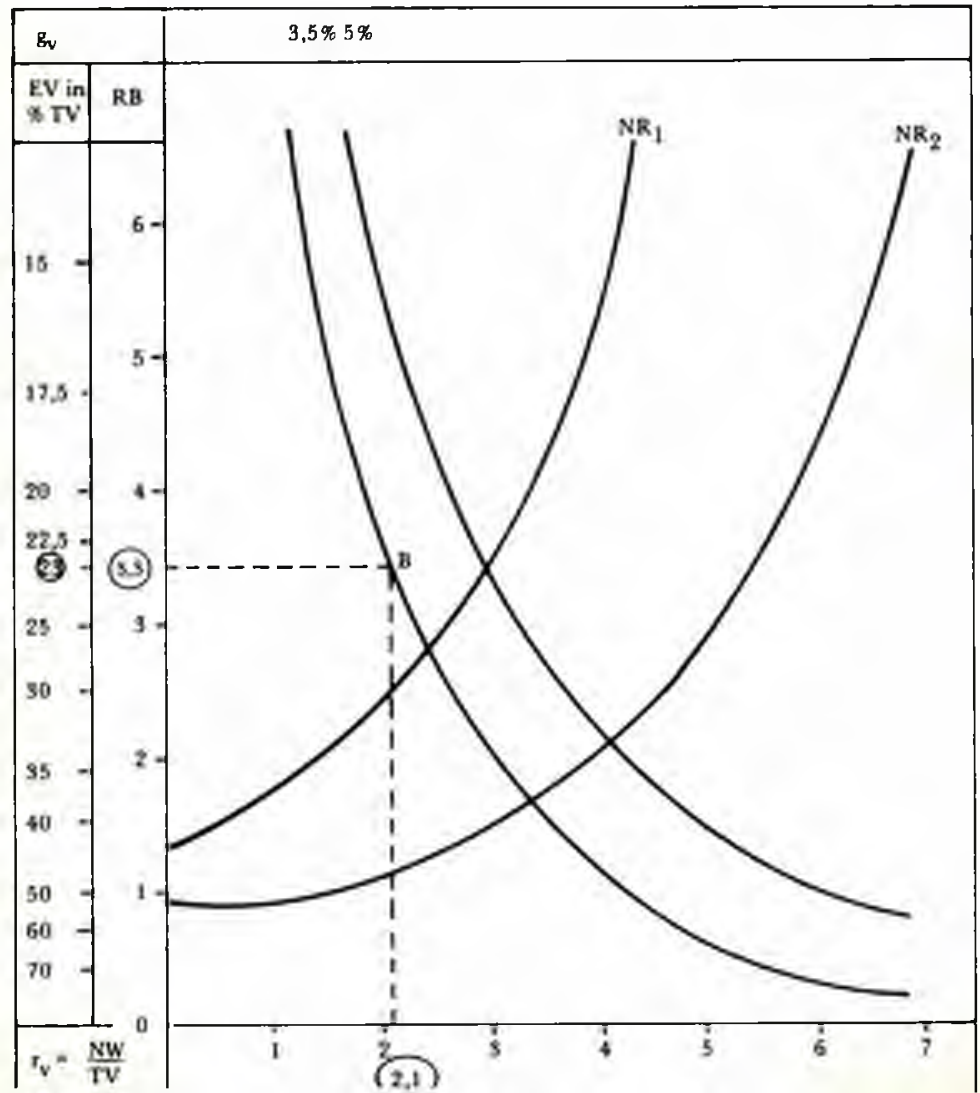


Grafiek 6

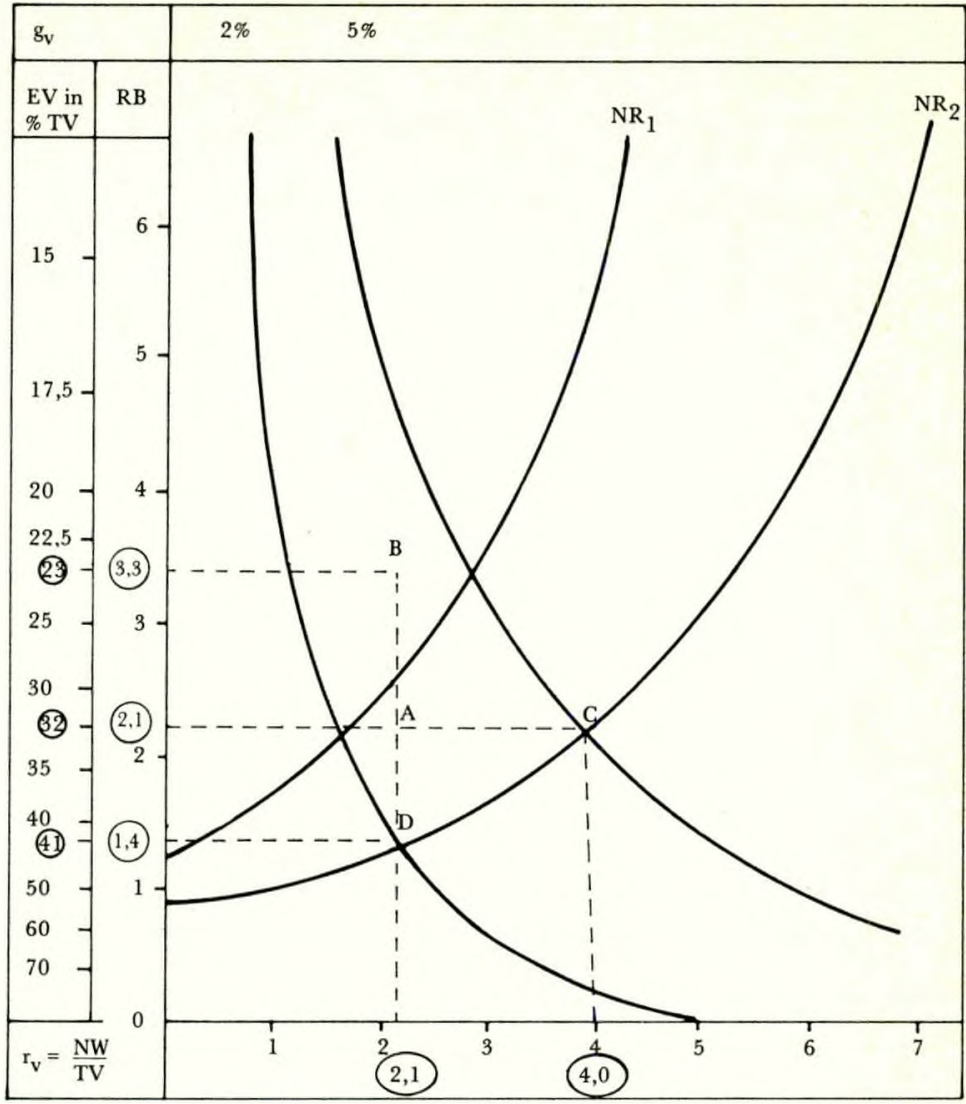

De ondernemingsleiding zal dienen te streven naar een herstel van een evenwichtige groei en zal daarbij een keuze maken die ligt tussen twee extreme mogelijk. heden (zie grafiek 6).

In het eerste geval zal zij er naar streven de rentabiliteitsverslechtering van de bestaande aktiviteitengebieden ongedaan te maken door nieuwe projekten te en. tameren met een hoge rentabiliteit (= expansie-, diversificatie-, of omstructure. ringsbeleid). Zij zal daarbij de groeivoet handhaven op 5\% die, indien de renta. biliteitsverwachting $r_{v}$ gebaseerd is op optimale kosten. en prijscondities, slechts gerealiseerd zal kunnen worden door aanvankelijk een nog groter financieel ri. sico te accepteren dan $\mathrm{RB}=3,3$.

De rentabiliteitsverwachtingen van de nieuwe projekten moeten dan echter van dien aard zijn dat daardoor de rentabiliteit van de gehele onderneming stijgt tot $r_{v}=4,0 \%$ waardoor het rentedragend vreemd vermogen daarna kan worden verminderd tot het niveau $\mathrm{RB}=2,1(=32 \% \mathrm{EV}$ in TV) is bereikt. De onderneming heeft dan de nieuwe „evenwichtssituatie” C bereikt. In dit alternatief wordt dus prioriteit gegeven aan herstel van de rentabiliteit door vergroting van de groei bij een aanvankelijke aanvaarding van een groter financieringsrisico.

In het tweede geval zal de ondernemingsleiding ernaar streven de nieuwe „evenwichtssituatie” D te bereiken door tijdelijk de groei zo sterk af te remmen 
dat de omvang van het rentedragend vreemd vermogen kan worden verminderd tot de positie $\mathrm{RB}=1,4$ is bereikt. Haar strategisch beleid op lange termijn wordt daarna afgestemd op het lagere groeitempo van $2 \%$. Laatstgenoemd beleid is derhalve gericht op het herstel van het financiële weerstandsvermogen, door primair het vreemd vermogen aan te passen aan de lagere rentabiliteitsverwachtingen.

Tussen beide extreme mogelijkheden - groeibeleid en herstel weerstandsvermogen - liggen een aantal alternatieve mogelijkheden waarbij de hier bedoelde evenwichtsstituatie bereikt kan worden. Deze evenwichtssituaties liggen dan tussen de posities $\mathrm{D}$ en $\mathrm{C}$ op de lijn $\mathrm{NR}_{2}$.

Door zowel interne als externe veranderingen kunnen de na te streven even. wichtssituaties steeds weer worden verstoord. Met behulp van modeltechnieken kunnen de factoren waarmede rekening gehouden moet worden bij het vaststellen van zulke evenwichtssituaties, expliciet gemaakt worden en onderling consistent worden afgewogen.

\section{Financiële ruimte en rentabiliteit van strategische projekten}

Evenzo kan op basis van de hiervoor beschreven methode worden vastgesteld welke financiële ruimte er in de komende jaren beschikbaar is voor strategische investeringen. Daarbij moet expliciet gemaakt worden:

- onder welke (externe en interne) condities deze ruimte beschikbaar komt

- welke doelstellingen daarbij de binnen de onderneming te onderscheiden ak. tiviteitengebieden dienen te behalen

welke financiële risico's daarbij aanvaard worden

welke minimale rentabiliteit de in te dienen strategische projekten dienen op te leveren.

In ons artikel in Schmalenbachs Zeitschrift für betriebswirtschaftliche For. schung ${ }^{16}$ ) is uitgewerkt op welke wijze dit sturingsinstrument in het planningsproces kan worden opgenomen. Zijn de uitgangspunten en doelstellingen eenmaal vastgelegd en aanvaard dan kan daaruit zowel de omvang van de financiële ruim te als de aanwending daarvan worden afgeleid.

Zou de ondernemingsleiding kiezen voor een groei van $5 \%$ - zoals in de grafieken 4 en 6 de punten A en $\mathrm{C}$ - dan bedraagt de maximale omvang voor be. talingen van reeds goedgekeurde of nieuwe strategische investeringen incl. daar. mede verbonden verhoging van het bedrijfskapitaal van het totale vermogen:

+ groeivoet

+ afschrijvingen

- produktiewaarborgende invest.

$=$ financiële ruimte

$$
\begin{aligned}
& 5 \% \\
& 5,7 \% \\
& 2,6 \% \\
& \hline 8,1 \%
\end{aligned}
$$

Deze financiële ruimte kan in de positie A en C onder „,normale risico"-condities worden gefinancierd nl. voor A bijeen gemiddeld eigen vermogensaandeel in het totale vermogen van $23 \%$ en een netto winst $r_{v}=2,9 \%$ over het totale vermogen en voor $\mathrm{C}$ bij een eigen vermogensaandeel van $32 \%$ en een netto winst van $r_{v}$

\footnotetext{
1980.

16) Die finanzielle Spielraumrechnung als strategisches Instrument. Wordt waarschijnlijk gepubliceerd in het eerste kwartaal
} 
$=4,0 \%$ over het totale vermogen. In de positie $\mathrm{D}$ is de groeivoet $\mathrm{g}_{\mathrm{v}}=2 \%$ en bedraagt de financiële ruimte $2,0+5,7-2,6=5,1 \%$ van het totale vermogen bij een netto winst $r_{v}=2,1 \%$ over het totale vermogen en gefinancierd met een gemiddeld eigen vermogensaandeel van $41 \%$. Hierbij zij nog eens met nadruk erop gewezen dat bij deze comparatief statische benadering de omvang van de finan ciële ruimte gebonden is aan de evenwichtssituatie, waarbij voorts verondersteld is dat deze evenwichtssituatie gedurende de gehele periode gehandhaafd kan blij. ven.

Zo zou bij de beweging van de positie $\mathrm{B}$ naar de positie $\mathrm{D}$ - gebaseerd op de doelstelling om het financiële weerstandsvermogen af te stemmen op de pessimistischer rentabiliteitsverwachtingen - het mogelijk zijn dat gedurende enige jaren ook een deel van de afschrijvingen zal moeten worden gebruikt voor de ver. mindering van het vreemd vermogen. Pas als de gemiddelde positie $\mathrm{D}$ is bereikt zal de financiële ruimte $5,1 \%$ van het totale vermogen bedragen.

Een van de belangrijkste condities voor de daadwerkelijke realisering van de omvang van de financiële ruimte is dat de binnen deze ruimte in te dienen strategische projekten tenminste aan een van te voren vastgestelde minimale rentabiliteitseis moeten voldoen. De minimale rentabiliteitseis wordt in eerste instantie vastgesteld in de evenwichtssituatie (in grafieken 4 en 6 de posities A, C en D). Dit houdt impliciet in dat de rentabiliteit van de onderneming zonder investerin. gen op de bij deze posities behorende niveaus kan worden gehandhaafd, als de optimale kosten-en prijscondities onveranderd blijven.

Veranderen deze wel dan kan de rentabiliteit gehandhaafd blijven als alle kostenstijgingen in de opbrengstprijzen kunnen worden doorberekend en/ of gecompenseerd door produktiviteitsstijgingen.

De evenwichtsposities worden door de volgende kengetallen gekenmerkt:

\section{Tabel 2:}

Aandeel eigen vermogen in $\%$ totale vermogen

Aandeel rentedragend vreemd vermogen in totale vreemd vermogen

Rentabiliteit voor afschrijvingen en rente

- Afschrijvingen

$=$ Rentabiliteit voor rente

/. Rente

- Rentabiliteit voor belasting

- Belastingen 50\%

= Rentabiliteit na belasting

- Dividend 60\%

$=$ Mutatie eigen vermogen

+ Mutatie vreemd vermogen

= Groei totaal vermogen

Totale investering

Produktiewaarborgende investeringen in

$\%$ van het totale vermogen

$\begin{array}{ccc}A & C & D \\ 23,00 & 32,00 & 41,00 \\ & & \\ 47,00 & 47,00 & 47,00 \\ 14,70 & 16,58 & 12,30 \\ 5,70 & 5,70 & 5,70 \\ 9,00 & 10,88 & 6,60 \\ 0,09 \times 0,77 \times 0,47 & 0,09 \times 0,68 \times 0,47 & 0,09 \times 0,59 \times 0,47 \\ 3,26 & 2,88 & 2,50 \\ 5,74 & 8,00 & 4,10 \\ 2,87 & 4,00 & 2,05 \\ 2,87 & 4,00 & 2,05 \\ 1,72 & 2,40 & 1,23 \\ 1,15 & 1,60 & 0,82 \\ 3,85 & 3,40 & 1,18 \\ 5,00 & 5,00 & 2,00 \\ 10,70 & 10,70 & 7,70 \\ & & \\ 2,60 & 2,60 & 2,60\end{array}$

Voor de vaststelling van de minimale rentabiliteitseis voor strategische projekten wordt ervan uitgegaan dat: 
- de rentabiliteit voor belasting slechts op het bedoelde evenwichtsniveau kan worden gehandhaafd door doorvoering van produktiewaarborgende investeringen

de produktiewaarborgende investeringen eveneens alle kosten (incl. rente) dekken die door deze investeringen worden veroorzaakt.

Onder de hiervoor genoemde condities kan de minimale rentabiliteit voor rente voor strategische investeringen als volgt worden berekend:

totale investering $\times$ rentabiliteit voor rente produktiewaarborgende investeringen $\times$ rente over het totale vermogen totale investeringen - produktiewaarborgende investeringen

Voor de onderscheiden evenwichtsposities zijn de percentages van de minimaal te behalen rentabiliteit voor rente evenals de daaruit af te leiden minimale ren. tabiliteit na belasting als volgt:

$\begin{array}{ll}\text { Rentabiliteit } & \text { Rentabiliteit } \\ \text { voor rente } & \text { na belasting }\end{array}$

A: $\frac{10,7 \times 9,0-2,6 \times 3,26}{8,1}=10,8 \% \quad 3,6$

C. $\frac{10,7 \times 10,88-2,6 \times 2,88}{8,1}=\quad 13,4 \% \quad 4,8$

D: $\frac{7,7 \times 6,6-2,6 \times 2,5}{5,1}=\quad 8,7 \% \quad 2,5$

In het voorgaande is ervan uitgegaan dat de rentabiliteit van de onderneming gehandhaafd kan blijven op het bij de evenwichtspositie behorende niveau door doorvoering van:

- produktiewaarborgende investeringen en

- strategische investeringen waarvan de rentabiliteit gemiddeld gelijk is aan een bij deze positie behorend minimale rentabiliteitsniveau.

Het is echter mogelijk dat door wijzigingen in het (externe) economische klimaat niet alleen de rentabiliteitsverwachtingen ongunstiger zijn, maar ook de financieringsvoorwaarden zich in ongunstiger zin ontwikkelen. (D.w.z. in grafiek 4 van de evenwichtspositie A naar de positie B). De rentabiliteit van strategische projekten zal dan aanzienlijk hoger moeten zijn om de in grafiek 6 ten doel gestelde evenwichtspositie $\mathrm{C}$ te bereiken. Niet alleen moet in dit geval door nieuwe strategische investeringen de rentabiliteitsdaling $\left(r_{v}\right.$ met $\left.0,8 \%\right)$ worden overbrugd maar door ongunstiger leningsvoorwaarden moet de doelstelling voor $r_{v}$ zelf nog eens met 1,1 punt worden verhoogd.

Welke minimale rentabiliteitseis voor strategische projekten daaruit afgeleid kan worden is mede afhankelijk van: 
- de tijd waarin de evenwichtspositie $\mathrm{C}$ bereikt zal moeten worden

- de middelen die daarvoor ter beschikking kunnen worden gesteld, en welk financieringsrisico daarmede aanvaard wordt

- het tempo waarin de nieuwe strategische investeringen de rentabiliteitsbij. drage leveren.

Het is duidelijk dat hiermede het terrein van de comparatieve statica is verla. ten.

De evenwichtspositie $\mathrm{C}$ kan gedurende de gemiddelde afschrijvingsperiode van de bestaande aktiviteiten bereikt worden indien:

- de nieuwe strategische projekten een rentabiliteit opleveren waarvan het ge. middelde gelijk is aan $4,8 \%$ (= rentabiliteit na belasting van evenwichtspositie

C)

- de groei van het totale vermogen afgestemd wordt op de zich verbeterende EV : VV-verhouding, beginnend met een groeivoet van $2 \%$ blijkens grafiek 5.

Dit beleid gaat er dus vanuit dat, als reactie op de pessimistischer rentabiliteits. verwachting van de bestaande aktiviteiten en de ongunstiger financieringsvoor. waarden, de oorspronkelijke groeivoet van $5 \%$ wordt aangepast aan het lager niveau van $2 \%$ en dat tegelijkertijd verwacht wordt dat nieuwe strategische projek. ten gemiddeld aan de bij positie $\mathrm{C}$ behorende (hogere) minimale rentabiliteitseis zullen voldoen. Gedurende de afschrijvingsperiode aanvaardt de ondernemings. leiding een meer dan ,normaal” financieringsrisico. De onderneming loopt daarbij het gevaar een onvoldoend financieel weerstandsvermogen te hebben bij hernieuwde ongunstige economische ontwikkelingen.

Lijkt dit gevaar op lange termijn aanwezig dan zal de ondernemingsleiding de voorbedoelde risicoperiode kunnen verkorten door een hogere rentabiliteitseis te stellen aan nieuwe strategische projekten dan $4,8 \%$. $\mathrm{Zij}$ zal dan echter de ver. minderde risico als gevolg van de verkorting van de risicoperiode moeten vervangen door een risico dat het gevolg is van de grotere omvang van het rente. dragend vreemd vermogen. Hierdoor kan een groeivoet gevolgd worden die groter is dan $2 \%$. Voorts zullen daarbij projekten met een korte omlooptijd de voorkeur verdienen.

Worden de ondernemingsrisico's (vooral ook op korte termijn), hoog ingeschat en komt de gemiddelde rentabiliteitsverwachting voor strategische projekten niet boven $2,5 \%$ uit, dan zal de ondernemingsleiding haar beleid meer richten op de evenwichtspositie $\mathrm{D}$ in grafiek 6 . In het kader van dat beleid wordt een direkte vermindering van het (rentedragend) vreemd vermogen nagestreefd door gedurende een aantal jaren ook een deel van de afschrijvingen te gebruiken.

Uiteraard gaat aan het hiervoor zeer summier beschreven afwegingsproces tussen groei, risico en rentabiliteit vooraf de afweging in hoeverre door andere maatregelen de eerder beschreven rentabiliteitsverslechtering ongedaan gemaakt kan worden.

Daarbij zal onderzocht moeten worden in hoeverre door:

- een gewijzigde markt- en prijspolitiek een betere opbrengsten- en kostenpositie kan worden bereikt

- rationalisatie de produktiviteit kan worden verhoogd

- samenwerking met andere ondernemingen een betere rentabiliteitsbasis voor te onderscheiden aktiviteitengebieden kan worden gerealiseerd 
- stilleggen van niet rendabele produktie-eenheden de gemiddelde rentabiliteit kan worden verbeterd

- gunstiger leningsvoorwaarden, al of niet voor specifieke projekten, het financieringsrisico kan worden verminderd

- vermindering van de produktiewaarborgende investeringen (groter produktierisico, andere milieu-eisen) de ruimte voor strategische investeringen kan wor. den vergroot.

Op basis van het door ons gehanteerde model kunnen de hier besproken vraagstukken in onderling verband worden gebracht zodat een consistente be sluitvorming wordt gewaarborgd.

Uit het voorgaande blijkt tevens dat het bedrag tot waartoe een onderneming bij haar groeibeleid gebruik zal kunnen maken van het leverage-effekt, begrensd wordt door haar streven naar een evenwichtige groei. Een evenwichtige groei is slechts gewaarborgd bij een gemiddelde financiering op lange termijn met een „normaal” financieringsrisico. In dit op continuïteit gericht beleid is tevens aangegeven welk rentabiliteitsniveau (strategische) projekten minimaal dienen te be. halen. Slechts onder de conditie dat nieuwe projekten aan deze rentabiliteitseis voldoen mag gebruik gemaakt worden van het leverage-effekt.

\section{Financieringsrisico en ondernemingsconceptie}

Bij de vaststelling van de solvabiliteitsgrens bestaat het gevaar dat eenzijdig gelet wordt op de vermogensstruktuur (passiefzijde van de balans). Dit is correct zolang het vermogen uitsluitend is vastgelegd in duurzame produktiemiddelen en bedrijfskapitaal. In dat geval kan de onderneming volledig beschikken over de totale cash flow die de eventueel te onderscheiden aktiviteitengebieden opleveren. Daartegenover is zij ook volledig verantwoordelijk voor het nakomen van de contractuele financiële verplichtingen. Zodra echter een deel van het vermogen vastgelegd wordt in niet geconsolideerde deelnemingen wordt op de balans van de concernonderneming slechts het aandeel van de concernonderneming in het zichtbare eigen vermogen van deze deelnemingen weergegeven. Bij een eventue. le latere consolidatie van een deelneming in de concernonderneming wordt dit aandeel vervangen door de verschillende groepen aktiva, voorzieningen en vreemd vermogen. Daardoor wordt het relatieve aandeel van het eigen vermogen in het totale vermogen van de concernonderneming lager. De vraag dient derhalve te worden behandeld in hoeverre bij de vaststelling van het „,normaal financieringsrisico" - en de daaruit af te leiden eigen-vreemd vermogen verhou. ding - rekening moet worden gehouden met financiële „rechten” en ,verplichtingen" met betrekking tot niet geconsolideerde deelnemingen.

In hoeverre een niet geconsolideerde deelneming bij de vaststelling van het „normale" financieringsrisico in feite beschouwd zal moeten worden als een ge consolideerde onderneming wordt bepaald door:

- juridische bindingen: „winstoverneming”, leninggarantie etc.

- maatschappelijke verplichtingen: vakbonden, overheden, imago verhinderen veelal de stillegging van betreffende deelneming en/of de deelneming is van dien omvang dat afstoten niet zonder meer mogelijk is

- ondernemingsconceptie: betreffende deelneming is van belang voor het realiseren van omschreven hoofddoelstellingen van de onderneming. 
Zodra deze of dergelijke voorwaarden zich voordoen wordt in wezen een blijvende economische band tussen de concernonderneming en de deelneming na. gestreefd. Bij de vaststelling van het „normaal” financieringsrisico zal een dergelijke deelneming behandeld moeten worden als een geconsolideerde onderneming ook al heeft de feitelijke consolidatie (nog) niet plaatsgevonden. De concern. onderneming zal de contractuele financiële verplichtingen van deze deelneming bij de vaststelling van het "normale" financieringsrisico moeten betrekken. Dit komt ook tot uitdrukking in het aandeel van het eigen vermogen in het totale vermogen zoals deze op de balans van de concernonderneming kan worden af. gelezen.

Het voorgaande kan schematisch als volgt worden verduidelijkt. Daarbij wordt ervan uitgegaan:

- dat alle deelnemingen op grond van voorgaande overwegingen als "geconsolideerde" deelnemingen moeten worden beschouwd, naar rato van het deelnemingspercentage

- dat deze deelnemingen een zichtbaar eigen vermogen hebben van 6

- dat de EV : VV-verhouding $35: 65$ is bij een „normaal” financieringsrisico.

De balans van deze - in de gepubliceerde balans niet geconsolideerde - deelne. mingen ziet er als volgt uit:

Deelnemingen

\begin{tabular}{lr|lr}
\hline Duurzame produktiemiddelen & 10 & Eigen Vermogen & 6 \\
Deelnemingen & 0 & Vreemd Vermogen & 11 \\
Bedrijfskapitaal & 6 & & \\
Liquide middelen & 1 & & 17
\end{tabular}

De balans van de overige - in de gepubliceerde balans wel geconsolideerde - ak. tiviteiten ziet er als volgt uit:

Geconsolideerde aktiviteiten

\begin{tabular}{lr|lr}
\hline Duurzame produktiemiddelen & 46 & Eigen Vermogen & 29 \\
Deelnemingen & 0 & Vreemd Vermogen & 54 \\
Bedrijfskapitaal & 27 & & \\
Liquide middelen & 10 & & -
\end{tabular}

De balans van de onderneming op basis waarvan het „normaal” financieringsrisico wordt berekend ziet er als volgt uit: 
Concernbalans (niet geconsolideerd)

\begin{tabular}{lr|lr}
\hline Duurzame produktiemiddelen & 56 & Eigen Vermogen & 35 \\
Bedrijfskapitaal & 33 & Vreemd Vermogen & 65 \\
Liquide middelen & $\frac{11}{100}$ & & \\
& &
\end{tabular}

In de gepubliceerde balans wordt van de niet geconsolideerde deelnemingen slechts het aandeel van de concernonderneming in het zichtbare eigen vermogen van deze deelnemingen getoond. De getoonde balans heeft derhalve de volgende struktuur:

Gepubliceerde (geconsolideerde) balans

\begin{tabular}{lr|lr}
\hline Duurzame produktiemiddelen & 46 & Eigen Vermogen & 35 \\
Deelnemingen & 6 & Vreemd Vermogen & 54 \\
Bedrijfskapitaal & 27 & & \\
Liquide middelen & $\mathbf{1 0}$ & & $\mathbf{8 9}$
\end{tabular}

Het aandeel van het eigen vermogen in het totale vermogen is dan $39 \%$.

\section{Tenslotte}

Met behulp van ons model voor de afweging van ondernemingsgroei, rentabi liteit en financieringsrisico wordt bereikt dat investeringsbeslissingen afgestemd worden op expliciet te stellen afwegingsfaktoren die liggen tussen strategische doelstellingen op lange termijn en financieringsrisico op korte termijn. Er bestaan geen modeltechnieken om het ondernemingsrisico uit te bannen.

Wel kan worden aangegeven welke risico's de ondernemingsleiding bij investeringsbeslissingen concreet loopt, zodat expliciet kan worden vastgesteld welke risico's en tot welke omvang deze bereid is te aanvaarden bij concrete investeringsbeslissingen.

Hierdoor is het tevens mogelijk om snel te reageren wanneer bedoelde risico. faktoren zich wijzigen. Daardoor blijft een groeibeleid op lange termijn afgestemd op kansen en gevaren op korte termijn. Een "groeibeleid" is dan tegelijkertijd een „overlevingsbeleid". 